Medieval Studies, vol. 22, 2018 / Studia z Dziejów Średniowiecza, tom 22, 2018

\author{
Piotr Samól
}

(Gdansk Univeristy of Technology)

https://orcid.org/ 0000-0001-6021-1692

\title{
Borrowing Images of Empire: The contribution of research on the artistic influence of the Holy Roman Empire on Polish Romanesque architecture in the eleventh and twelfth centuries ${ }^{1}$
}

Keywords: Romanesque architecture, Poland, Ostrów Lednicki, monumental stone buildings

Although knowledge concerning Romanesque architecture in Poland has developed over many years, most cathedrals and ducal or royal seats have not been comprehensively examined. Moreover, a substantial number of contemporary scholarly works have erased the thin line between material evidence and its interpretation. As a consequence, the architectural remains of Polish Romanesque edifices are often considered the basis for wider comparative research. Meanwhile, fragmentarily preserved structures of Romanesque buildings have allowed scholars to conduct research on their origins and models, but they have rarely provided enough information for spatial reconstructions of them. This means that one might investigate the process of transposing patterns from the Holy Roman Empire to Poland instead of the influence of Polish masons' lodges on each other. Therefore, this paper has two aims. The first is to look at how imperial patterns affected the main stone structures (cathedrals and collegiate

1 Originally, my paper entitled 'In the Shadow of Salian and Hohenstaufen Cathedrals: The Artistic Influence of the Holy Roman Empire on Polish Romanesque Architecture in the Eleventh and Twelfth Centuries' was given at the 'Borrowing Images of Empire' seminar during the Medieval Congress in Leeds in July 2014. This extended version has been rewritten as a result of discussions following that presentation. 
churches) in Poland before Germanic urbanisation in the thirteenth century. The another is to analyse, how the changes in knowledge of Imperial archetypes might influence the interpretation of their Polish copies. ${ }^{2}$

The key problem with regard to researching Polish architecture from the eleventh and twelfth centuries is the lack of appropriate written sources to investigate chronology. Apart from short notes from annals and chronicles about dates of the consecration of major religious buildings, ${ }^{3}$ there is no other reliable information about the origins of Romanesque architecture. Therefore, one should take account of the results of research that has been carried out by art historians and archaeologists. However, it is necessary to make the methodological statement that only recognisable and authentic remains of Romanesque buildings can be considered as material sources for their history. Because most early stone buildings were transformed, rebuilt, or simply destroyed in following centuries, it is methodologically dubious to adopt theoretical reconstructions, which are usually based on comparative studies of existing and other reconstructed architecture. ${ }^{4}$ One should rather reverse the method of research: instead

2 Information about German Romanesque architecture in Poland is based mostly on synthetic works (e.g. G. Dehio, Geschichte der Deutschen Kunst, Bd. 1, Berlin 1932; E. Badstübner, Kirchen der Mönche. Die Baukunst der Reformorden im Mittelalter, Berlin 1980; D. von Winterfeld, Romanik am Rhein, Stuttgart 2001), as well as on annual seminars held by art historians from both countries.

3 For example, the rebuilt cathedral in Gniezno was thought to have been consecrated in 1064, although the archbishopric was restored only in 1076, and Gall mentions its consecration in 1097. See Z. Świechowski, Katalog architektury romańskiej $w$ Polsce [Catalogue of Romanesque Architecture in Poland], Warszawa 2009, p. 89.

4 In particular, methodological difficulties with regard to comparative research in architecture may be seen in the history of the reconstruction of what is referred to as the "second" Wawel Cathedral. Most of its Romanesque elements were discovered and preserved by Adolf Szyszko-Bohusz in the first half of the twentieth century. Since that time, subsequent generations of art historians, archaeologists, and architects have somewhat reinterpreted the same corpus of source materials. Some scholars (e.g. Z. Dmochowski, Dzieła architektury $w$ Polsce [Works of Architecture in Poland], London 1956, p. 5.) have found the patterns related to four-tower imperial cathedrals in the Rhineland and Swabia. However, the archaeological research of Janusz Firlet and Zbigniew Pianowski in the 1990s and 2000s did not confirm such a thesis; both Firlet and Pianowski ('Nowe odkrycia i interpretacje architektury przedromańskiej i romańskiej na Wawelu' [New discoveries and interpretations of Pre- and Romanesque Architecture on Wawel Hill], in: Architektura romańska w Polsce. Nowe odkrycia i interpretacje. Materiały z sesji naukowej w Muzeum Poczatków Państwa Polskiego. Gniezno 9-11.04.2008 [Romanesque Architecture in Poland. New discoveries and interpretations. Materials from the Scientific Conference at the Museum of Origins of Poland, 
of making visualisations of unpreserved historic edifices, one should focus on checking and analysing the common roots of their creation and the ways in which similar patterns were transposed.
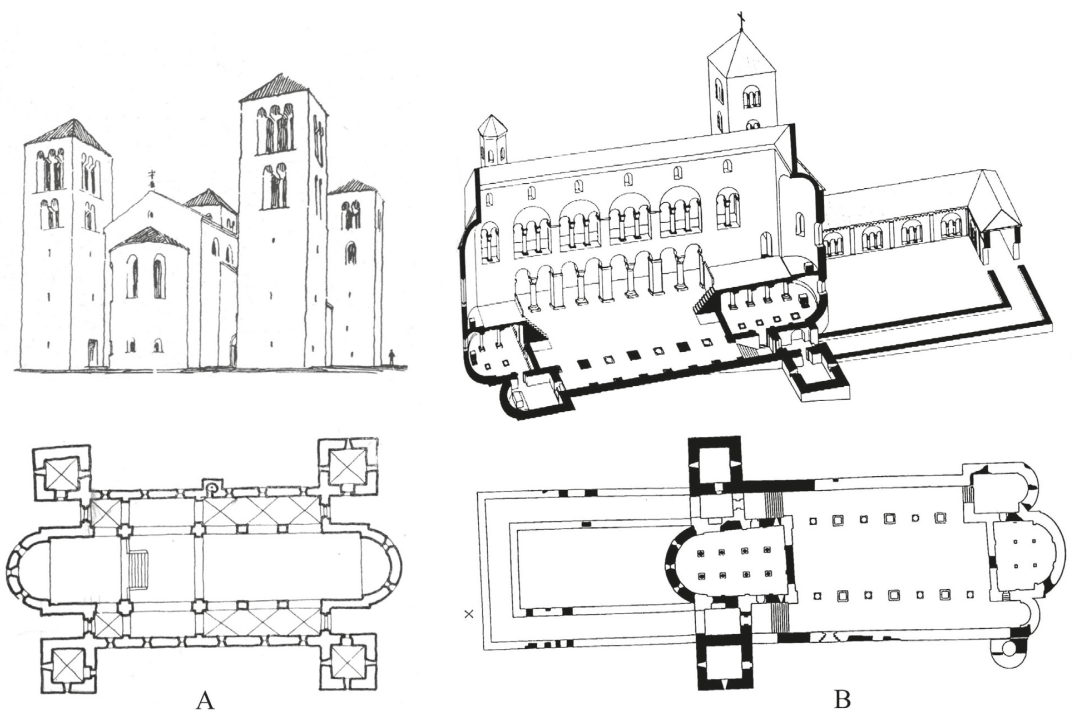

Fig. 1. Reconstructions of "second" Wawel cathedral (completed in 1142): A - with four towers (source: Z. Dmochowski, Historia architektury polskiej: rysunki do skryptu, Sekcja Wydawnicza Z.S.A.,1948, p. 5); B - with two towers and atrium (source: J. Firlet, Z. Pianowski, 'Nowe odkrycia...,' p. 257). Existing original walls were marked with black colour

Gniezno 9-11 April 2008], ed. T. Janiak, Gniezno 2009, pp. 251-278) suggest that Wawel Cathedral would rather have had only two rectangular towers and no transept. Further publications may illustrate the methodological weakness of proposing too-detailed hypotheses. Most current scholars agree that Wawel Cathedral was larger and had two galleries over the side naves, although there was no architectural or archaeological evidence to confirm such an argument. The only premise was a similarity to the collegiate-church in Tum (near Łęczyca) and a group of ecclesiastical buildings in Germany (e.g. the collegiate-church in Quedlinburg or Magdeburg). After the archaeological excavations in front of the western side of the cathedral, the reconstruction of the Romanesque church was extended by a western atrium, which was similar to one from the Benedictine monastery in Maria Laach. One may conclude that the more years which have passed since the most recent significant discovery, the more distinguished and rich are the reconstructions of Wawel Cathedral that are proposed. Meanwhile, one may be sure that the "second Wawel cathedral" alluded to the ecclesial architecture of Rheinland, but details remain uncertain. 
'Borrowing Images of Empire' was a natural process when a civilisation on a lower level of development was faced with one which was stronger and more developed. ${ }^{5}$ Inevitably, there must exist some medium allowing for the transposition of models. In early medieval Europe, this function was ascribed to the Church, whose existence was nevertheless strongly dependent on the support provided by the state. Therefore, baptism was the key factor in the creation of a central authority in the first Slavic states, such as Great Moravia, Bohemia, and Poland, and this helped the leaders of these polities to be recognised by other Christian states. ${ }^{6}$ The cooperation between the structures of church and state, along with the numerous positive effects it had in post-Carolingian Europe (e.g. in the Ottonian Empire), also served as the basis for the development of the Polish state in the very first centuries following its emergence.

However, discussion of the origins of the political elites of Poland is still vital. Scholars agree that in the second half of the tenth century, to the east of Germany, a new political organism was formed under the rule of Mieszko, his son Bolesław, and their successors. The westward territorial expansion of the Polans was faced with the claims of German borderland lords, who strove to gain control over the lands belonging to the Polabian Slavs and other Slavic tribes. ${ }^{7}$ According to older literature, the rough relationship between the Empire

5 The idea of transposing ('borrowing') architectural patterns in the Middle Ages is one of the paradigms of the history of art. See T. Rodzińska-Choraży, Zespoty rezydencjonalne i kościoły centralne na ziemiach polskich do połowy XII wieku [Residences and central churches in Poland till the half of twelfth century], Kraków 2009, pp. 285-286. One may observe the same process in contemporary anthropological research. See E. Domańska, Mikrohistorie. Spotkania w mikroświatach [Micorohistories. Meetings in micro-worlds], Poznań 2006, pp. 85-86.

6 On the other hand, the Church played an important role in unifying the ethnic groups of post-Carolignian Germanic states (J. Sochacki, Formowanie się wczesnośredniowiecznego państwa niemieckiego w latach 919-962 [Process of creation of early-medieval Germany in the years 919-962], Słupsk 2013, pp. 97-104; D.A. Sikorski, 'Chrystianizacja germańskiej Germanii od VI do początku IX wieku' [Christianization of Germania from the sixth to the early ninth centuries], in: Chrystianizacja Europy. Kościoty na przetomie I $i$ II tysiaclecia [The Christianization of Europe. Churches at the Turn of the First and Second Millennia], eds. J. Dobosz, J. Strzelczyk, Poznań 2014, pp. 241-243.

7 P. Urbańczyk, Mieszko Pierwszy Tajemniczy [Mieszko I, the 'Mysterious'], Toruń 2012 , p. $317 f f$. This monograph has been critically reviewed by D.A. Sikorski in 'Mieszko Pierwszy Tajemniczy i jeszcze bardziej tajemnicza metoda historiograficzna' [Mieszko I, the 'Mysterious,' and a much more 'mysterious' method of historiography], RH, 79, 2013, p. 183. He argues that several of Urbańczyk's statements, including analyses of Romanesque architecture, are not proven. 
and Mieszko could be seen as one of the motives pushing the duke to accept baptism from the hands of Bohemia intermediaries, who were vassals of the Ottonian Kingdom. ${ }^{8}$ By becoming part of the Christian world the duke was forced to pay tribute to the emperor for at least some of his lands. As a result of a conflict with Margrave Odo I of Ostmark, Bolesław - Mieszko's son and a future king - was temporarily sent to the imperial court as a hostage. The ruler himself, in turn, participated in imperial congresses in Quedlinburg in 973, 986, and 991. In 981, Mieszko married Oda of Haldensleben, the daughter of Dietrich, Margrave of the Northern March, thus establishing an affinity with the Saxon aristocracy. From then on the dynastic relationships of representatives of the Piast dynasty with dukes and rulers of the Reich played a major role in the transposition of architectural models.

According to Hanna Kóčka-Krenz, a new archaeological excavation on Temple Isle (in Polish Ostrów Tumski) in Poznań has proved that a ducal palace with small private chapel may have been constructed by Mieszko for his first wife, Dąbrówka. ${ }^{9}$ Even if one rejects that hypothesis, ${ }^{10}$ it is certain that Poznan was the location of one of the oldest stone complexes in the Piast state. Perhaps another one was built in Gniezno. New archaeological findings have led Przemysław Urbańczyk to formulate the quite controversial hypothesis that Poznan Cathedral was founded by Mieszko for Unger, the second missionary bishop in Poland. ${ }^{11}$ Unger was ordained around 982, but political disturbances in the Empire during the childhood of Otto III

8 However, before circa 974, the Church in Bohemia was directly dependent upon the bishopric in Regensburg. D.A. Sikorski, Kościót w Polsce za Mieszka I i Bolesława Chrobrego. Rozważania nad granicami poznania historycznego [The Church in Poland during the reigns of Mieszko I and Bolesław the Brave. Thoughts on the limitations of historical research], Poznań 2013, pp. 91-107.

9 H. Kóčka-Krenz, 'Początki monumentalnej architektury świeckiej na grodzie poznańskim' [Origins of monumental secular architecture in the stronghold in Poznań], in: Poczatki architektury monumentalnej $w$ Polsce. Materiaty z sesji naukowej. Gniezno 20-21 listopada 2003 roku [Origins of monumental architecture in Poland. Materials from the Academic Conference. Gniezno 20-21 November 2003], eds. T. Janiak, D. Stryniak, Gniezno 2004, pp. 71-82; eadem, 'Rezydencje pierwszych piastowskich władców na poznańskim grodzie' [Ducal residences of first Piasts in the stronghold in Poznań], Nauka, 2, 2005, p. 91; G. Pac, Kobiety w dynastii Piastów. Rola społeczna piastowskich żon i córek do połowy XII wieku-studium porównawcze [Women in the Piast dynasty. The social role of Piast wives and daughters to the middle of the twelfth century], Toruń 2013, pp. 188-202.

10 D.A. Sikorski notes that building Christian sacred structures in Poznań before Mieszko's baptism would be pointless. See D.A. Sikorski, Kościót w Polsce..., p. $110 \mathrm{ff}$.

11 P. Urbańczyk, Mieszko Pierwszy..., pp. 257ff, 302. 
would have caused the regent empress Teofano to decide not to grant investiture to Unger. Urbańczyk argues that Mieszko could have started building the first monumental church in expectation of Unger's arrival. Although Urbańczyk's hypothesis is not completely convincing and has been strongly criticised by Dariusz A. Sikorski, ${ }^{12}$ one can agree that there were convergent links between plans for Poznań Cathedral and the imperial monastery in Memleben. ${ }^{13}$ Maintaining scepticism over the precise chronology of Romanesque stone structures, ${ }^{14}$ it is much more likely that construction began after Bishop Unger moved to Poland. Thus, the plan of the cathedral is one of the pieces of evidence allowing its construction to be dated..$^{15}$ According to the analysis of Aneta Bukowska, Poznań Cathedral had its origins in OttonianCarolingian models. ${ }^{16}$

The character of the extensive early-medieval economy was the reason why a duke, just like an emperor, was constantly travelling, accompanied by his retinue. He had to spend much time on routine tours around the main strongholds of his territory. This model stemmed both from the need to manage the country and difficulties in providing supplies, which could result from the court remaining in one place for

12 D.A. Sikorski, 'Mieszko Pierwszy...,' p. 193.

13 A. Bukowska, 'Forma i geneza pierwszej katedry w Poznaniu' [The first cathedral in Poznań - its architectural form and origins], in: Architektura romańska w Polsce. Nowe odkrycia $i$ interpretacje [Romanesque architecture in Poland. New discoveries and interpretations], ed. T. Janiak, Gniezno 2009, pp.175-207; eadem, Najstarsza katedra $w$ Poznaniu. Problem formy $i$ jej genezy $w$ kontekście architektury około roku 1000 [The oldest cathedral in Poznań. Problems of architectural form and its origins in the context of architecture around year 1000], Kraków 2013; in her study, Bukowska proposes a new interpretation of the remains of the Romanesque Poznan cathedral. She proves that the first stone church must have been erected around 985 and after its destruction was rebuilt in the middle of the eleventh century. The entire complex was transformed at the beginning of the twelfth century (p. 164).

14 See P. Urbańczyk, 'Akceleratorowa chronologia najstraszej architektury murowanej w Polsce' [Acceleration chronology of the oldest stone architecture in Poland], in: Architektura romańska w Polsce. Nowe odkrycia..., pp. 33-49; D.A. Sikorski, 'O nadziejach związanych z metodą datowania $14 \mathrm{C}$ zabytków architektury średniowiecznej w Polsce (głos w niedokończonej dyskusji)' [Hopes connected with the C14 methods of dating of medieval monuments in Poland (comment from an unfinished discussion)], in: Architektura romańska w Polsce. Nowe odkrycia..., pp. 677-702.

15 D.A. Sikorski, Wczesnopiastowska architektura sakralna (jako źródto historyczne dla dziejów Kościoła w Polsce) [Early-medieval sacred architecture in Poland (as historical evidence for the history of the Church in Poland)], Poznań 2012, pp. 60-62.

16 A. Bukowska, Najstarsza katedra w Poznaniu..., pp. 240-246; however, her proposed reconstruction is more similar to St. Michael's Church in Hildesheim than to the Benedictine monastery in Memleben. 

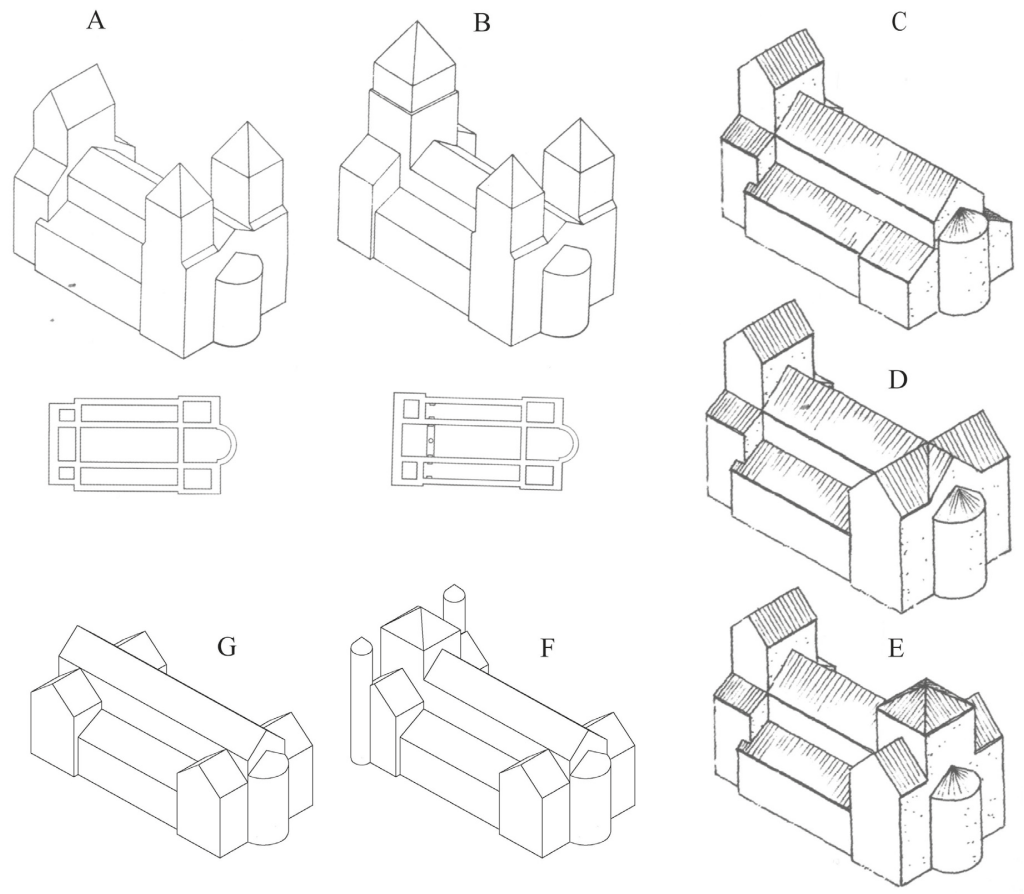

Fig. 2. Reconstructions of Poznań cathedral: A - in 985 (according to K. Józefowiczówna), B - in 1034 (according to K. Kunarzewska), C, D, E - three variations of the cathedral in 985 (according to Z. Świechowski), F - at the end of $10^{\text {th }}$ century (according to A. Bukowska), G - around 1030 (according to A. Bukowska); source: A. Bukowska, Najstarsza katedra w Poznaniu..., pp. 22-24 and 243-244

too long. Therefore, a duke did not reside in one capital, but instead stayed in at least several administrative centres throughout the year. This mechanism meant that the first manifestation of the artistic influence that the Empire exerted on Poland lay in building ducal seats. However, scholars do not agree when exactly the programme of constructing stone palaces began. Attempts at dating these structures has had differing results. Many scholars have suggested that the emergence of the palas could be observed in the late tenth century, ${ }^{17}$

17 This is a result of what is referred to as 'Millennial Research' conducted in the 1960s. Thirty years later, the dendrochronologic method allowed the precise establishment of the chronology of the wooden construction of the strongholds. However, 
but others, for example Zbigniew Świechowski, have proved that, except for Poznań, there is no evidence that ducal palaces had been built before the second decade of the eleventh century. ${ }^{18}$ Nevertheless, these were structures modelled on German Kaiserpfalz, ${ }^{19}$ although naturally far more modest in design. In Gniezno, Ostrów Lednicki, and Giecz, the palas consisted of a great masonry hall, designated for the ruler, several neighbouring rooms, and a rotunda-shaped chapel. ${ }^{20}$ It should be borne in mind that a major role in the process of transposition of manor-house architectural patterns to Poland was played by the personal relationship of Bolesław with the Emperor Otto III. Not only did Bolesław pay visits to imperial strongholds, ${ }^{21}$ but he also hosted the emperor during the Synod of Gniezno in 1000. Such close relations were rooted in Otto's conviction that Slavs constituted one of the four pillars of the Christian world. Although this universalist programme failed after the emperor's death, that was not tantamount

archaeologists who try to date stone structures still have to rely on more traditional methods.

18 See reference no. 13. Z. Świechowski and P. Urbańczyk base their assumptions on the reinterpretation of $14 \mathrm{C}$ methods. According to them, ducal palaces in Great Poland were built almost a half century later than had been thought. D.A. Sikorski ('O nadziejach...,' passim) is sceptical of their results, because, as he notes, these techniques never give a precise date but instead offer $60 \%$ accuracy within a fifty-year period.

19 D. von Winterfeld, Ch. Herrmann, 'Die Vor- und Hochromanische Architektur (10.-12. Jahrhundert), in: Mittelalterliche Architektur in Polen. Romanische und gotische Baukunst zwischen Oder und Weichsel, eds. D. von Winterfeld, Ch. Herrmann, Petersberg 2015, pp. 42-45. See also K. Stala, Architektura rezydencji wczesnośredniowiecznych w Polsce. Próba reinterpretacji dotychczasowych pogladów z uwzględnieniem tta europejskiego [Architecture of Early-medieval residences in Poland. An attempt at reinterpreting the current state of knowledge], Kraków 2013, pp. 139-141. Stala makes a common mistake in interpreting destroyed architectural monuments: she decides to reconstruct not only the general volumes of ducal places, but also height and even the precise composition of elevations or scheme of features. Archaeological research does not provide the information needed to create such detailed reconstructions; therefore, her configurations are really speculative hypotheses.

20 Z. Pianowski, „Sedes regni principales”. Wawel $i$ inne rezydencje piastowskie do połowy XIII wieku na tle europejskim ["Sedes regni principales". Wawel and other Piast residences up to the middle of the thirteenth century], Kraków 1997, pp. 85-92; T. Rodzińska-Chorąży, Zespoty rezydencjonalne i kościoły centralne..., pp. 44-58.

21 See J. Strzelczyk, Bolestaw Chrobry, Warszawa 2014. Bolesław may have taken part in imperial congresses in Quedlinburg, Magdeburg, and Regensburg. His son Mieszko II was a hostage in 1014 during the war between Bolesław I and Emperor Henry II. 
to the breaking of cultural ties. Construction of a palas continued during the first years of the rule of Bolesław's son, Mieszko II. ${ }^{22}$

Along with the palas, the early eleventh century saw the rise of the first cathedrals in the Polish ecclesial metropolises of Gniezno, ${ }^{23}$ Kraków, ${ }^{24}$ and Wrocław. ${ }^{25}$ Attempts to establish a temporary bishopric of Kołobrzeg failed, possibly around 1007. The recognised architectural form of these ecclesiastical buildings was simple: they were transept-less basilicas terminating in apses. Both the palas and the first cathedrals are classified as pre-Romanesque. Moreover, although the buildings alluded in design to Ottonian patterns, by the 1030s there were hardly any qualified teams of masons and sculptors acquainted with the rules of Romanesque detail composition and creation. Therefore, one could suppose that all of the early stone structures in Poland were constructed by craftsmen who had come from the Empire and were financed by the duke. The recently discovered remains of the churches in Kałdus and Giecz can also be ascribed to that period. ${ }^{26}$

22 Archaeological excavations in the strongholds of Giecz and Kałdus prove that a crisis in the 1030s caused the breakdown of central developments such as building stone churches.

23 J. Zachwatowicz, 'Gród gnieźnieński i pierwsze kościoły' [The stronghold in Gniezno and the first churches], in: Katedra Gnieźnieńska [The Cathedral in Gniezno], ed. A. Świechowska, Poznań-Warszawa-Lublin 1970, pp. 11-22, Tab. II; idem, 'Katedra romańska' [The Romanesque cathedral], in: Katedra Gnieźnieńska..., pp. 23-34, Tab. VIII; T. Janiak, 'Problematyka wczesnych faz kościoła katedralnego w Gnieźnie,' [Problems in interpretation of the first stages of the Cathedral in Gniezno], in: Poczatki architektury monumentalnej..., pp. 99-126.

${ }_{24}$ See reference no. 3; T. Węcławowicz, Krakowski kościół katedralny w wiekach średnich. wi możliwości interpretacji [The Cathedral in Kraków in the Middle Ages. Its features and possibilities of interpretation], Kraków 2005, pp. 21-45 suggests that there might have existed a so-called "double cathedral" in the eleventh century.

25 E. Małachowicz, 'Dwie romańskie katedry we Wrocławiu' [Two Romanesque cathedrals in Wrocław], in: Architektura romańska $w$ Polsce. Nowe odkrycia..., pp. 95-105; idem, Katedra wroctawska. Dzieje i architektura [The Cathedral in Wrocław. History and Architecture], Wrocław 2012, pp. 39-67.

26 W. Chudziak, Wczesnośredniowieczna przestrzeń sakralna 'in Culmine' na Pomorzu Nadwiślańskim [Early-medieval sacred space 'in Culmine' in Pommerania], Toruń 2003, pp.77-96; idem, 'Geneza wczesnoromańskiej bazyliki z Kałdusa na Pomorzu Nadwiślańskim' [Origins of the early-medieval basilica in Kałus], in: Poczatki architektury monumentalnej... [Origins of monumental architecture...], pp. 245-256; T. Krysztofiak, 'Wczesnopiastowski kościół pw. św. Jana Chrzciciela na grodzie w Gieczu w świetle najnowszych odkryć' [The early medieval St. John the Baptist's church in the stronghold in Giecz (based on new discoveries)], in: Poczatki architektury monumentalnej..., pp. 181-198. The church in Giecz probably had two circular towers on both sides of its western façade. Similarities to Ottonian architecture are so strong 
Although the destruction of the main centres of the Piast state during the Bohemian invasion of 1038 marked a symbolic milestone between pre-Romanesque and Romanesque architecture, it made no difference in erecting monumental edifices. During the restoration of the Piast Kingdom under the rule of Kazimierz in the middle of the eleventh century, the court was dependent upon imperial support, and, consequently, it used the same architectural models.

The overthrow of Mieszko's reign in 1031, the division of the country between his brothers and cousin, the subsequent failed attempt to restore central power, the outbreak of a pagan revolt (around 1032), and the Bohemian invasion of 1038 brought chaos to Poland. Mieszko's son Kazimierz, whose mother Richeza was Otto III's niece, fled to Germany. It comes as no surprise that Emperor Henry III, because of the increasing power of the Duchy of Bohemia, eventually decided to support Kazimierz in his plans to retake the throne. As the major administrative centres of Poland had been destroyed, Kazimierz chose Kraków as his main seat, where the construction of St. Gereon's Church was underway. ${ }^{27}$ Although it is believed that Bishop Aaron, a Benedictine monk from Cologne, contributed to the construction of the building, the structure itself rather indicates Saxon influences. ${ }^{28}$ The transept with its galleries and its elevated eastern choir are evocative of the solution employed in, inter alia, St. Michael's Church in Hildesheim. However, it should be noted that St. Gereon's Church lacked the symmetry between the eastern and western parts typically observed in older Ottonian architecture. That was the reason

that some scholars quoted in this paper interpret the uncertain remains of foundations in the western parts of the excavated building as imitations of imperial westworks.

27 Z. Świechowski, Katalog..., p.24; Z. Pianowski, „Sedes regni principales”..., pp. 27-30.

28 Undoubtedly bishop Aaron was the protector of Richeza and, thus, he might have kept in touch with Prince Kazimierz. Moreover, the patron's name, St. Gereon, was connected with a church in Cologne. Kazimierz probably established the Benedictine monastery in Tyniec. An analysis of the influence of women from the Piast dynasty on Polish Romanesque architecture is conducted by Świechowski in his most recent paper: Z. Świechowski, 'Udział małżonek Piastów w procesie powstawania budowli w XI i XII wieku' [The participation of Piast wives in the process of building in the eleventh and twelfth centuries], in: Architektura sakralna w poczatkach państwa polskiego (X-XIII wiek), [Sacred architecture during the beginnings of the Polish state (tenth to thirteen centuries)], eds. T. Janiak, D. Stryniak, Gniezno 2016, pp. 147-170. 
why St. Gereon's Church is thought to be modelled on Lower Saxon and Rhineland patterns.

Until the end of the 1070s all recognised monumental stone buildings in Poland were connected with the Saxon cultural sphere. Although the political centre of the Empire was moved to the south during the reign of the Salian dynasty, ecclesial connections with Magdeburg and relationships with Piast's relatives did not favour the adoption of new architectural solutions. Therefore, the first signs of a diversity of architectural patterns may be observed after the collapse of the reign of king Bolesław II in 1079. His successor, Władysław Herman was married to Judith, the step-daughter of Emperor Henry III. According to Świechowski, the standard Romanesque monumental architecture in Poland from the late eleventh and twelfth centuries may be divided into two groups. ${ }^{29}$ The first group comprises buildings still under the influence of Lower Saxon and Turin architecture, therefore directly linked to the patterns popularised owing to the relationships with the court of the Liudolfing and Salian dynasties, as well as the House of Hohenstaufen. The other is the Rhineland and Alsatian group. In the latter case, the manner of transposing the patterns of imperial cathedrals and Alsatian churches into the Polish context is more difficult to grasp. Perhaps a significant factor in bringing masons' lodges from those areas could be the relationships of some of the Polish bishops with German and French borderland areas. One could mention here such figures as bishops Maurus, Alexander of Malonne, and Baldwin Gall. ${ }^{30}$ The nationality of Polish bishops may be a premise for identifying the origins of architectural patterns.

\footnotetext{
29 Z. Świechowski, Sztuka polska. Romanizm [Polish Art. Romanesque], Warszawa 2004, pp. 64-103.

30 The issue of the nationality of some Polish bishops is analysed by D.A., 'Die Rolle der Geistlichen ausländischer Herkunft in der Polnischen Kirche des 10-12. Jahrhundert,' in: Fernhändler, Dynasten, Kleriker: die piastische Herrschaft in kontinentalen Beziehungsgeflechten vom 10. bis zum frühen 13. Jahrhundert, eds. D. Adamczyk, N. Kersken, Wiesbaden 2015, pp. 241-262. Bishop Baldwin and his successor, Maur, probably came from the French-imperial border. See Z. Budykowa, 'Maur,' in: Polski stownik biograficzny, vol. 20/2, issue 85, pp. 261-262. One may assume that their personal relationships with Rhineland were crucial for transferring the architectural patterns of Wawel Cathedral. Similar indications can be seen in the case of the bishops (and brothers) Alexander of Malonne and Walter. The first of those was bishop of Płock and was mentioned as the initiator of the construction of a Romanesque cathedral in Płock. According to scholars, that church alluded to Rhineland three-conch churches. Alexander's brother Walter, who became Bishop of Wrocław, was a significant person for the history of the extension of the cathedral in Wrocław.
} 

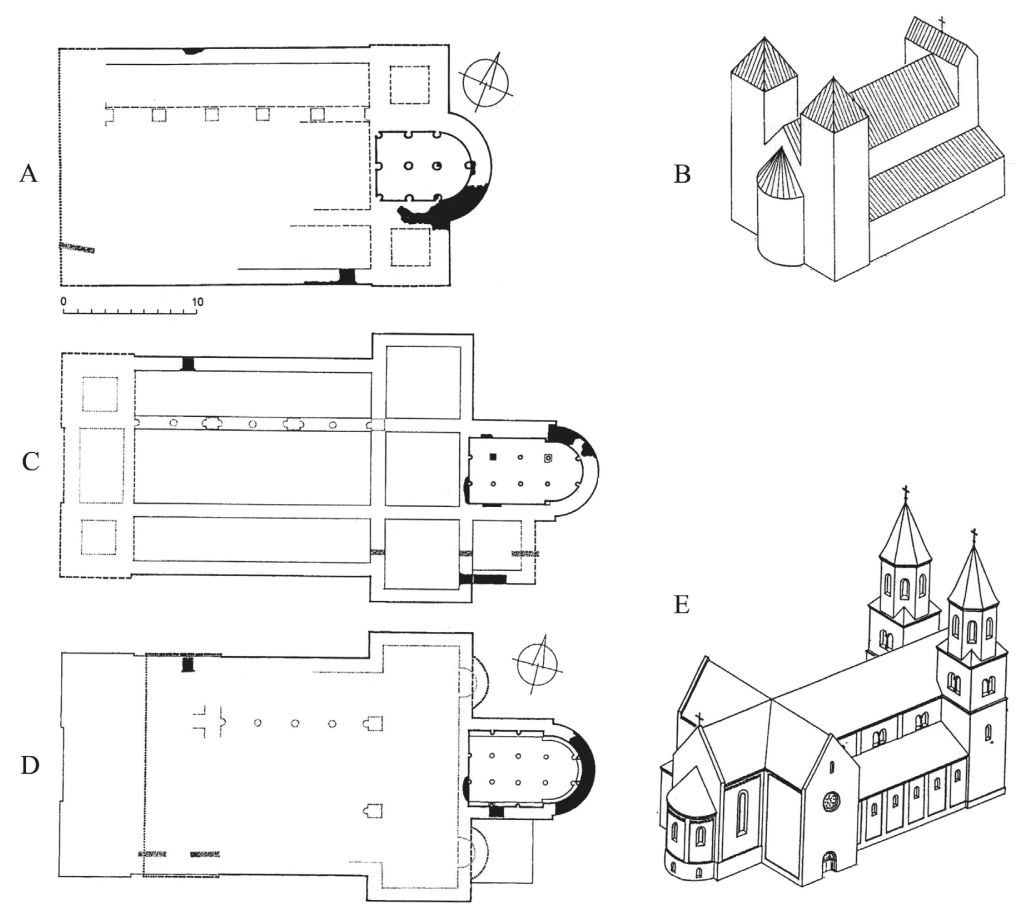

Fig. 3. Reconstructions of three Wrocław cathedrals by E. Małachowicz (Existing original walls were marked with black colour) $\mathrm{A}, \mathrm{B}$ - plan and axonometric view of cathedral around 1030, C - plan of "second cathedral", D, E-plan and axonometric view of cathedral around 1200; source: E. Małachowicz, Dwie romańskie katedry..., pp. 96, 103

A similar situation may be seen in St. Gilles' Collegiate Church in Kraków, which was founded by Sieciech, a palatine of duke Władysław Herman, around $1100 .{ }^{31}$ The façade of the collegiate church corresponds to the architectural solutions employed in Lower Saxony, inter alia in the Marktkirche St. Cosmas and Damian in Goslar. On the first floor there is a gallery between the towers, over which another, private storey, designated for the ruler, was constructed. The spatial arrangement of the Kraków church is much more modest in comparison to its German prototype; yet the significance of the Kraków

${ }_{31}$ M. Bober, Architektura przedromańska i romańska w Krakowie. Badania $i$ interpretacje [Pre-Romanesque and Romanesque architecture in Kraków. Research and interpretations], Rzeszów 2008, pp. 79-86. 
of the eleventh century differs from that of Goslar. At the time, Kraków temporarily lost its capital city functions to Płock, while Goslar remained one of the imperial seats.

A building that without a doubt constitutes the work of a Saxon or Turin masons' lodge is some thirty years younger: the St. Peter and Paul collegiate church in Kruszwica. Here the masons' marks can actually still be seen on the façade. The church was probably erected as a cathedral for the transitory bishopric in Kruszwica; however, due to the fall of that bishopric in the mid-twelfth century only a fragmentary group of canons remained with the church. ${ }^{32}$ The eastern part of the church shows the links of the masons' lodge with monastic architecture, as the presbytery ends with an apse, and on both sides symmetrically adjacent chapels are also terminated in apses. On the western side, traditionally, a complex of towers was constructed, and there might have been a gallery, too. Similar solutions from the early twelfth century are found, for example, in the imperial Benedictine monasteries in Königslutter and Paulinzella. Both of them used to be a Benedictine monastery modelled on the Hirsau reform, which meant a simplification of the layout of the eastern chapels in comparison to the solutions seen in Cluny. In Poland, the monasteries erected in the spirit of the Hirsau reform include the Benedictine monasteries in Ołbin and Trzemeszno ${ }^{33}$ and the Norbertine monastery in Strzelno. What is more, the Saxon architecture of the collegiate church in Kruszwica, the Christianizing mission in Pomerania (conducted by Otto of Bamberg), and the attempts to subordinate the Polish dioceses to the archbishops of Magdeburg might indicate the region which artistic models came from.

A special case among the churches representative of Saxon architecture is St. Martin's collegiate church in Opatów. It was founded by

32 Shortly after the conquest of Pomerania in the 1120 s, three bishoprics were established for this region, those in Wolin, Kruszwica, and Włocławek. It soon transpired that two Polish dioceses were too weak to coexist; therefore the bishopric of Kruszwica was divided and subordinated to the archbishop of Gniezno and the bishop of Włocławek. See M. Szczepan, 'Przynależność kościelna ziemi sławieńsko-słupskiej w XII in a poczatku XIII wieku' [Ecclesial divisions of the region of Słupsk and Sławno], Studia z Dziejów Średniowiecza, 17, 2013, pp. 227-252.

33 Z. Świechowski, Katalog..., pp. 24-25; R. Kunkel, 'Architektura opactw benedyktyńskich w Polsce wczesnośredniowiecznej' [Architecture of Benedictine Abbeys in Medieval Poland], Fontes Archaeologici Posnanienses. Annales Musei Archaeologici Posnaniensis, 49, 2013, pp. 77-85. 
Duke Henryk Sandomierski prior to $1150 .{ }^{34}$ Some scholars indicate links with Alsatian architecture, pointing to the horizontal wall partitions and towers divided by cornices. However, it is probable that those patterns were transposed from the much closer Quedlinburg, where the construction of the westwork of St Servatius collegiate church commenced after 1070; it strongly resembled the western part of the church in Opatów. ${ }^{35}$ Furthermore, the layout of the entire western part with the transept corresponds to the solutions applied in the sacral buildings of the Saxon tradition, e.g. in the Liebefraukirche in Halberstadt. Initially the presbytery concluded in an apse; in the late twelfth century the apse was replaced with a straight wall, indeed resembling trends in the architecture of Alsace and Burgundy.

As has already been mentioned, the other group of churches comprises those modelled on the sacred buildings of Rhineland and Alsace. The first of the great churches classified as part of this group is Wawel Cathedral, the construction of which began during the reign of Bolesław II. The Polish ruler helped Pope Gregory VII during his conflict with Henry III. After the humiliation of the emperor in Canossa, in return for the help given to the pope, Bolesław II was crowned king. At that time, he started the construction of a new cathedral on Wawel Hill. The construction was continued by his brother and his nephew, and it was only seventy years later, in 1142, that the cathedral was consecrated by Bishop Robert. ${ }^{36}$ The involvement of bishops Baldwin and Maur is also probable, the latter being buried in the western crypt in 1118 . The cathedral differed from any sacral building previously constructed in Poland, in that from the east and from the west it terminated in apses with crypts. The influence of the contemporaneously constructed imperial cathedrals in Speyer, Mainz, and Worms is apparent not only in the symmetry of the interior, but also in the spreading of the western towers protruding over the body of the nave. A hypothesis has been put forward in recent

34 A. Tomaszewski, Romańskie kościoły z emporami zachodnimi na obszarze Polski, Czech $i$ Węgier [Romanesque churches with internal galleries in Poland, Bohemia, Moravia, and Hungary], Wrocław-Warszawa-Kraków-Gdańsk 1974, pp. 97-100; Z. Świechowski, Katalog..., pp. 340-351.

35 J. Jarzewicz, 'Opatów a Quedlinburg, czyli o wnioskach z analogii’ [Opatów and Quedlinburg. Conclusions by analogy], in: Architektura romańska w Polsce. Nowe odkrycia..., pp. 323-340.

36 Bishop Robert could not have been involved in the construction of Wawel Cathedral, because he was transferred from Wrocław to Kraków in 1142. See D.A. Sikorski, Die Rolle der Geistlichen..., p. 258. 
years about the existence of a western atrium, similar to the one in the church of Maria Laach. ${ }^{37}$ The main problem in classifying the patterns of Wawel Cathedral is the fact that material evidence of its Romanesque architecture is much more uncertain than any theoretical reconstructions.

References to Wawel Cathedral and indirectly to its Rhineland prototypes may be seen in one of the best-preserved Romanesque churches in Poland: the collegiate church of St. Mary and St. Alexius in Tum, near Łęczyca. Although its present form is the effect of restoration work after World War II, its shape is generally authentic. The church (consecrated in 1161) was founded by an anonymous hierarch of the church, whose grave is located in the western apse. This indicates a similar functional designation as exists in the case of the western crypt in Wawel Cathedral. The purpose behind building such a grand basilica is unclear. After the construction of the church in Eęczyca was completed, in the twelfth and thirteenth centuries it was the venue of several dukes' congresses. The western apse contains also an apsidiole designated for a bishop's throne, although an independent bishopric has been never established there. The final stage of the church construction came in the period of feudal fragmentation; perhaps Prince Bolesław IV the Curly, the ruler of Łęczyca, sought to create a new diocese separate from the Gniezno metropolis. Most certainly, the team of masons constructing the cathedral in Tum was one of the best in Poland. Analysing the architectural details, Świechowski points out the existence of relationships between the masons there and the builders of the cathedral in Mainz. ${ }^{38}$

Both of the double-choir basilicas in Kraków and Tum lacked a transept. Although the interior of the Tum church was probably divided by a rood screen, the lack of a transept was aimed at introducing a more homogenous mass to the building and creating a sense of balance between the eastern (sacrum) and the western (profanum) parts. The Czerwińsk church of the Canons Regular was designed in a similar vein, although without a western apse; the long body of the nave smoothly turned into a presbytery terminated in apses. ${ }^{39}$

$37 \quad$ See reference no. 3.

38 A. Tomaszewski, Romańskie kościoły..., pp. 105-109; Z. Świechowski, Sztuka polska..., p. 67; idem, Katalog..., pp. 554-574.

39 A. Tomaszewski, Romańskie kościoły..., pp. 100-104; Z. Świechowski, Katalog..., pp. 55-65. 
In more dated literary references, a truly exceptional case with regard to Romanesque architecture in Poland is the attempt to reconstruct the cathedral in Płock. Due to an incorrect interpretation of the layout of the Renaissance cathedral, which was subject to inadequate maintenance in the nineteenth century, a triple-concha design similar to the ones known from Cologne was supposedly discovered there. Archaeological research showed, however, that in the sixteenth century the Romanesque cathedral was stripped to its foundations, and the only remnant of this is architectural detail in the form of crude granite blocks and double columns with cushion capitals. ${ }^{40}$ Some scholars attribute the work to a team of masons from the borderland areas of France and Flanders, the place of origin of Alexander of Malonne. ${ }^{41}$ Nothing certain can be said about the bulk of the building itself.

\section{$* * *$}

In conclusion, one can say that there were no traditions of monumental stone construction in Slavic Poland before the tenth century. Moreover, as Sikorski notes, palaces erected in the main strongholds of Greater Poland were local phenomena, because there were no similar structures in Prague or other political centres of Bohemia and Moravia. ${ }^{42}$ The patterns typically found there were transmitted along with the adoption of Christianity, and even though they sometimes pertained to secular architecture (palas), cathedrals, and collegiate churches embody the greatest achievements of Romanesque architectural design. Owing to limitations of space, in this paper there is no mention of parish churches, although some of them also fall into the division into two groups as described above. The teams which erected the main Romanesque buildings derived initially from Ottonian

40 The remaining part of an apse was found by the northern wall of the cathedral in 1981. See R. Kunkel, 'Sprawozdanie z terenowych prac badawczych i pomiarowych Instytutu Podstaw Rozwoju Architektury Politechniki Warszawskiej' [Report from field-work conducted by the Institute of the Development of Architecture, Warsaw University of Technology], Kwartalnik Architektury i Urbanistyki, 26, 1981, issue 3-4, pp. 294-305; idem, 'Katedra płocka w średniowieczu' [Płock cathedral in the Middle Ages], Biuletyn Historii Sztuki, 51, 1988, no. 3, pp. 187-200.

41 Z. Świechowski, 'Dwunastowieczna katedra w Płocku’ [The twelfth-century cathedral in Płock], Ochrona Zabytków, 5, 1952, pp. 174-189. The Norman form of cushion capitals might be considered as proof of French origins. This assumption corresponds with the fact that Bishop Alexander probably came from the northern provinces of France.

42 D.A. Sikorski, 'Mieszko Pierwszy...,' pp. 193-194. 

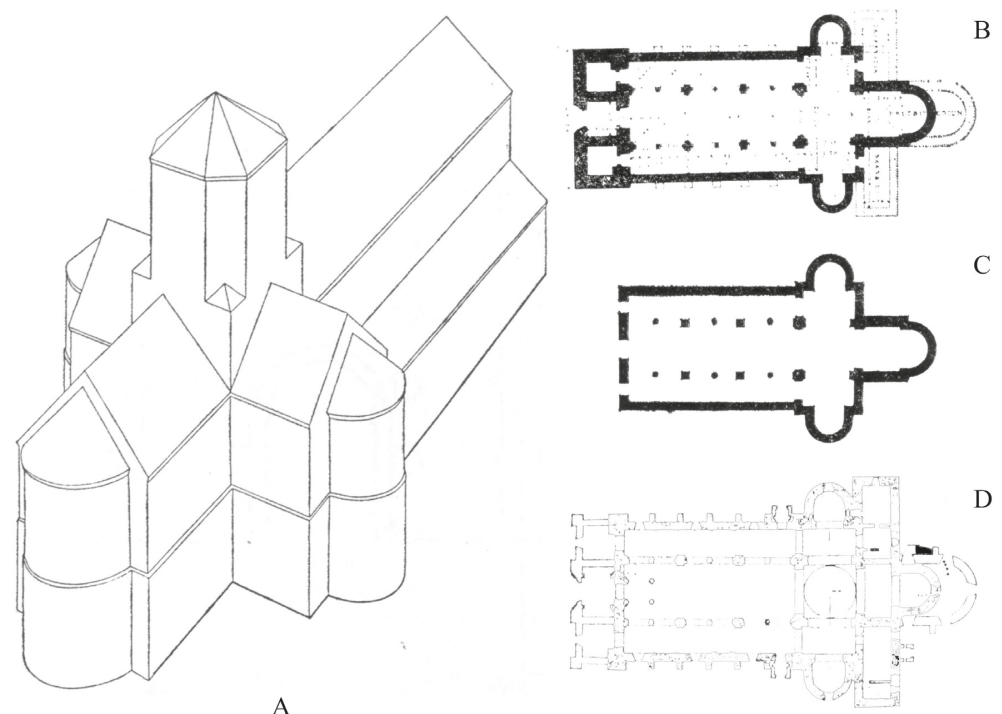

B

$\mathrm{C}$

D

A

Fig. 4. Reconstructions of Płock cathedral (completed in 1144): A - axonometric view (by Z. Świechowski), B - plan (by W. Łuszczkiewicz), C - plan (by Z. Świechowski), D - plan with marked (black colour) existing parts of Romanesque cathedral (by R. Kunkel); source: R. Kunkel, Sprawozdanie..., p. 299

architectural traditions, but later came either directly from Saxony and Turin, or they transposed patterns from the Rhineland and Alsace. A considerable role in bringing them to Poland must be attributed to the demands of partaking in the political life of the Empire, as well as to certain bishops coming from those regions. Further research on the Polish episcopate in the Middle Ages might allow one to formulate more precisely arrangements concerning the origins of the masons' lodges which worked in Poland.

Finally, there can be no doubt that the development of local building teams was connected with urbanization in the thirteenth century. Initially, German settlers in Central Europe brought new methods of construction and craftsmen who reproduced the architectural models typical for regions from which they came. This process might be observed not only in Poland (especially in Silesia), but also in the Czech and Slovak lands (e.g. Spiska Kapitula), or Hungary (e.g. St. Peter's 
Church in Herina and other Romanesque churches in the Siebenbürgen). ${ }^{43}$ The economic revolution in Central Europe brought the end of stone architecture and replaced it with building in a new material: brick. The simplicity of brick production and its increasing popularity led to newly located cities becoming the centres of a local building market. Moreover, those new circumstances broke the monopoly of the central authorities in the creation of monumental architecture which was based on imperial patterns.

43 M. Machowski, 'Sztuka romańska w Europie Środkowo-Wschodniej’ [Romanesque art in Eastern-Central Europe], in: Sztuka Świata [World Art], vol. 3, Warszawa 1993, pp. 414-415. 